\title{
Effects of antibrowning solution and chitosan-based edible coating on the quality of fresh-cut apple
}

\section{Lucimeire Pilon*}

Postharvest Laboratory, Embrapa Instrumentação,

Rua: XV de novembro, 1452,

13560-970, São Carlos, SP, Brazil

E-mail: lucimeire.pilon@yahoo.com.br

*Corresponding author

\section{Poliana Cristina Spricigo}

Federal University of São Carlos,

Rod. Washington Luís, km 235 - SP-310,

13565-905, São Carlos, SP, Brazil

E-mail: polianaspricigo@yahoo.com.br

Douglas de Britto,

Odilio Benedito Garrido Assis and Adonai Gimenez Calbo

Embrapa Instrumentação,

Rua: XV de novembro, 1452,

13560-970, São Carlos, SP, Brazil

E-mail: britto@cnpdia.embrapa.br

E-mail: odilio@cnpdia.embrapa.br

E-mail: adonai@cnpdia.embrapa.br

\section{Antonio Sergio Ferraudo}

State University of São Paulo,

Rodovia de acesso Prof. Paulo Donato Castellane,

CEP 13560-970, Jaboticabal, SP, Brazil

E-mail: fsajago@gmail.com

\section{Marcos David Ferreira}

Embrapa Instrumentação,

Rua: XV de novembro, 1452,

CEP 13560-970, São Carlos, SP, Brazil

E-mail: marcosferreira@cnpdia.embrapa.br 
Abstract: Fresh-cut apples were treated with an antibrowning solution and with a chitosan-based edible coating associated to antibrowning agents and the effects on the deterioration at low temperature were studied. The combined effect of ascorbic acid (AA), citric acid (CA) and chitosan was also evaluated. Control, coated and uncoated apples were packed in polyethylene terephthalate trays and the changes in headspace atmosphere, colour, firmness and microbial growth measured along ten days of storage at $5^{\circ} \mathrm{C}$. The samples coated with $1 \%$ $\mathrm{AA}+2 \% \mathrm{CA}+$ chitosan maintained a good colouration until day 6 , similar to those treated with $1 \% \mathrm{AA}+2 \% \mathrm{CA}$ without chitosan. Afterwards, the fruits became darker and similar to the control. A slight reduction in the rates of $\mathrm{CO}_{2}$ production was observed in all samples. Ethylene increased continuously during storage although gas production was extremely low. Texture did not change for all treatments; showing values around 9.0 to $10.0 \mathrm{~N}$. Growth of Salmonella, and total and fecal coliforms were not detected. The chitosan coating treatment was the most effective in inhibiting growth of moulds and yeasts, with count of $1.7 \mathrm{CFU} \mathrm{g}^{-1}$. Chitosan coating could be an alternative for preserving quality of fresh-cut 'Gala' apples. Results from this study suggest that.

Keywords: apple; chitosan; ascorbic acid; citric acid; firmness; colour; $\mathrm{CO}_{2}$; ethylene; microorganisms.

Reference to this paper should be made as follows: Pilon, L., Spricigo, P.C., de Britto, D., Assis, O.B.G., Calbo, A.G., Ferraudo, A.S. and Ferreira, M.D. (2013) 'Effects of antibrowning solution and chitosan-based edible coating on the quality of fresh-cut apple', Int. J. Postharvest Technology and Innovation, Vol. 3, No. 2, pp.151-164.

Biographical notes: Lucimeire Pilon currently works as a Post Doctor Associate at the Postharvest Laboratory at Embrapa (Brazilian Agricultural Research Corporation) in São Carlos, Brazil. She received her BSc in Agronomy from Federal University of Lavras in 2000, MSc in Science and Food Technology from University of São Paulo in 2003, PhD in Nuclear Energy in Agriculture and Environment in 2007 from University of São Paulo, Brazil, and Pos-Doc from University of Florida, USA. Her focus areas include minimal processing of fruit and vegetables and edible coatings.

Poliana Cristina Spricigo is currently a doctoral student in Biotechnology at the University Federal of São Carlos, working with the group of Postharvest Laboratory at Embrapa (Brazilian Agricultural Research Corporation) in São Carlos, Brazil. She received her BSc in Agronomy from São Paulo State University and MSc in Postharvest Technology from State University of Campinas. Her focus areas include postharvest technology in fruits, vegetables and flowers.

Douglas de Britto holds a BSc in Chemistry from Chemistry Institute (IQSC-USP) and has specialised in polysaccharide synthesis and its applications in his MSc and PhD courses. In 2006, he entered at EMBRAPA (Brazilian Company of Agricultural Research) to study the properties of chitosan derivative as edible coating in apple. He has published several works in this area showing the mechanical and physical chemistry properties, antifungal activity and browning effect controlling of such coating and film. Currently, he is working with chitosan nanoparticles to perform controlled release of nutrients and active packaging at EMBRAPA. 
Odilio Benedito Garrido Assis currently works as a Senior Researcher at Embrapa (Brazilian Agricultural Research Corporation) Instrumentation Unit in São Carlos, Brasil. He received his BSc in Physics from State University of São Paulo, Brasil, in 1983 and his PhD in 1995 in Materials Science from Federal University of São Carlos, Brazil. He has published several papers on materials science with focus on biopolymers applications in refereed international journals. He is also the author of some chapters related to post-harvest and new packaging technologies.

Adonai Gimenez Calbo graduated in Agronomy at the University of São Paulo in 1975. He received his Masters in Plant Physiology from the Federal University of Viçosa in 1978 and $\mathrm{PhD}$ from the University of California at Davis in 1985. He is working for Embrapa (Brazilian Agricultural Research Corporation) since 1976 in the following areas: plant physiology, post harvest, instrumentation for water relations and irrigation scheduling. $\mathrm{He}$ is the co-author of three books. He has authored and co-authored some scientific papers and has contributed to the development of two new commercial instruments, Irrigas for irrigation scheduling and Wiltmeter to measure leaf cell turgor pressure.

Antonio Sergio Ferraudo graduated in Mathematics at the State University of São Paulo in 1976. He received his Masters in Postharvest Physiology from Agricultural from University of São Paulo in 1988, and PhD from State University of São Paulo in 1993. He currently works as a Professor of Statistics at State University of São Paulo. His focus area is multivariate analysis, statistical process control, artificial neural networks and geoprocessing. He has published several articles on that field of study.

Marcos David Ferreira graduated in Agronomy at the University of São Paulo in 1986. He received his Masters in Postharvest Physiology from University of Florida in 1994, PhD from University of São Paulo in 1999, and post-doc from Texas A\&M in 2000. He currently works as a Senior Researcher at Embrapa (Brazilian Agricultural Research Corporation) Instrumentation Unit in São Carlos, Brazil, in the following areas: postharvest physiology, handling, sorting, food safety, packaging of fruits and vegetables. He is the editor of two books and has published several articles on that field of study.

This paper is a revised and expanded version of a paper entitled 'Avaliação microbiológica e fisiológica de maçã minimamente processada' presented at VI Encontro Nacional de Processamento Mínimo de Frutas e Hortaliças, Nova Friburgo, RJ, Brazil, 5th May - 3rd June 2011.

\section{Introduction}

Fresh-cut differ from whole fruit and vegetables in terms of their physiology, handling and storage requirements. In general, the disruption of tissue and cell integrity resulting from processing decreases the product shelf life. Besides, these products require more attention due to the magnitude of enzymatic and respiratory factors and microbial growth that may impact consumer safety (Lamikanra, 2002). Many techniques such as low temperature and high relative humidity, use of additives, controlled and modified atmosphere packaging and edible coating, have been applied in order to minimise these factors (Cantwell and Suslow, 2002; Sonti et al., 2003). 
Edible coatings, for example, have been suggested as low-cost alternative technology for preserving intact and fresh-cut fruit and vegetables since they can create semi-permeable barriers to gases and water vapour avoid microorganism contamination and help the preservation of produce quality (Olivas and Barbosa-Canovas, 2009). When the coat is formed, a modified atmosphere is developed and along with relative humidity and optimum refrigeration temperature, so fresh-cut products can have their shelf life extended significantly (Rojas-Grau et al., 2008). Polysaccharide-based coatings have been one of the most used materials to formulate preservative coating on fresh-cut products. Chitosan, a deacetylated polysaccharide from chitin, is able to coat and preserve quality of fruit and vegetables by forming films, which decreases respiration rates, inhibits microbial growth and consequently delays ripening. The film forming ability and antimicrobial properties of chitosan is well reported and successful tested in the storability of perishable foods (No et al., 2007; Olivas and Barbosa-Canovas, 2009).

A combination of elements can be used to improve preservation of fresh-cut products. In this sense, edible coatings can also be used as carriers of additives, including chemical agents with inhibitory action on enzymatic browning such as ascorbic acid that has action in reducing o-quinones to colourless diphenols and, citric acid that presents dual effects as lowering $\mathrm{pH}$ and as a copper chelate from polyphenol oxidase active site (Garcia and Barrett, 2002). In postharvest practice, ascorbic acid is currently applied in combination with others organic acids to prevent enzymatic browning and maintain fruit firmness (Qi et al., 2011).

Fresh-cut apple in slices form appears in the first place amongst minimally processed fruit or vegetable products found in the market (Toivonen et al., 2010), and their sale are projected to continue growing (Wang et al., 2007).

In this work, the preservative coating of fresh-cut 'Gala' apples was compared between samples dipped in a citric-ascorbic acid solution and samples coated with chitosan associated with citric and ascorbic acids and their main quality attributes investigated.

\section{Materials and methods}

\subsection{Materials}

Chitosan (Medium molecular weight, $75-85 \%$ degree of deacetylation, viscosity of 200-800 cP, Sigma-Aldrich, Inc., St. Louis, MO, USA) was the primary ingredient for the coating formulation. Citric acid (Synth Ltd., Diadema, SP, Brazil) was added to chitosan and keep a low pH for a complete dissolution. Ascorbic acid (Synth Ltd., Diadema, SP, Brazil) was used as antibrowning agent. Sodium dichloroisocyanurate dehydrate (Sumaveg ${ }^{\circledR}$, JohnsonDiversey Brasil Ltda., Sao Paulo, SP, Brazil) was used to sanitise apples before dipping.

\subsection{Preparation of the aqueous and coating solutions}

The antibrowning solution $(\mathrm{pH} 2.08)(1 \% \mathrm{AA}+2 \% \mathrm{CA})$ was prepared by dissolving ascorbic acid $\left(10 \mathrm{~g} \mathrm{~L}^{-1}\right)$ and citric acid $\left(20 \mathrm{~g} \mathrm{~L}^{-1}\right)$ in distilled water. The chitosan coating formulation (1\% $\mathrm{AA}+2 \% \mathrm{CA}+$ chitosan) was prepared by dissolving chitosan $\left(2 \mathrm{~g} \mathrm{~L}^{-1}\right)$ in citric acid solution $\left(20 \mathrm{~g} \mathrm{~L}^{-1}\right)$, while stirring at $70^{\circ} \mathrm{C}$. The ascorbic acid $\left(20 \mathrm{~g} \mathrm{~L}^{-1}\right)$ was 
added to the solution at room temperature prior to processing the fruit. The final $\mathrm{pH}$ of this formulation was measured as 2.17 .

\subsection{Fresh-cut fruit coating}

Before processing, all utensils and surfaces that would be contact with the fruit during processing were washed and sanitised with $200 \mathrm{mg} \mathrm{L}^{-1}$ sodium hypochlorite solution ( $\mathrm{pH}$ 7). 'Gala' apple fruit (Malus $x$ domestica Borkh.) were purchased from a local wholesale distributor at commercial maturity. Apples were selected by uniform size, discarding those with mechanical or any signal of pathological injuries. The fruit were stored at $5 \pm 1{ }^{\circ} \mathrm{C}$ until being processed. The fruits were then washed, sanitised by immersion in a $200 \mathrm{mg} \mathrm{L}^{-1}$ sodium dichloroisocyanurate dehydrate solution for $3 \mathrm{~min}$ and rinsed prior to slicing. Then, apples were cored and manually cut into wedges (average weight at $25 \pm 2 \mathrm{~g}$ ) with a sharp stainless steel knife. The apple wedges were then rinsed in a $20 \mathrm{mg} \mathrm{L}^{-1}$ sodium dichloroisocyanurate dehydrated solution for $3 \mathrm{~min}$. After, rinsing slices were separated in three lots and treated as follow:

1 immersion into $2 \%$ citric acid for $2 \mathrm{~min}$

2 immersed into the coating formulation $1 \%$ ascorbic acid $+2 \%$ citric acid $+2 \mathrm{~g} \mathrm{~L}^{-1}$ chitosan for $2 \mathrm{~min}$

3 as control lot: the wedges conserved as only sanitised.

Excess solution was allowed to drain and the samples, portions of approximately $200 \mathrm{~g}$ of fresh-cut apples placed into polyethylene terephthalate trays $(160 \mathrm{urn}, 750 \mathrm{~mL}$, Galvanotek $^{\circledR}$, Brazil) and stored in a cold room at $5 \pm 1{ }^{\circ} \mathrm{C}$. Analyses were carried out every other day for ten days.

\subsection{Headspace gas analysis}

Headspace gases within the sealed trays were sampled to determine the levels of $\mathrm{CO}_{2}$ and ethylene during storage. A septum consisted of a polyamine screw and a nut with a $7 \mathrm{~mm}$ hole filled with silicone adhesive was placed in the tray lid to collect the gases. The septum was sealed with two flexible silicone rings on the inside and outside of the lid. To measure the atmosphere, a $1-\mathrm{mL}$ headspace sample was withdrawn from the trays through the septum by piercing it with a needle on a syringe. The contents of these trays were used for subsequent fruit analysis. The gas samples were then injected into a C.G 3537-D gas chromatograph (C.G. Scientific Instrument, Sao Paulo, SP, Brazil) equipped with a $200 \mathrm{~cm}$ Porapak N column (Sigma-Aldrich, Inc., St. Louis, MO, USA), a thermal conductivity detector for $\mathrm{CO}_{2}$ and flame ionisation detector for ethylene. The injector, oven, and detector temperatures were held at ambient temperature $\left(23^{\circ} \mathrm{C}\right)$. The carrier gas was hydrogen for $\mathrm{CO}_{2}$ and nitrogen for ethylene, with a flow rate of $30 \mathrm{~mL} \mathrm{~min}$. Five measurements were made and $\mathrm{CO}_{2}$ and ethylene levels were calculated in comparison to a standard (ethylene: $87,681 \mathrm{uL} \mathrm{L}^{-1}$ and $\mathrm{CO}_{2}: 3,49 \mathrm{~mL} \mathrm{~L}^{-1}$ ).

\subsection{Texture measurement}

Texture of apple slices was determined using a TA.XTPlus Texture Analyser (Stable Micro Systems Ltd., England, UK) by measuring the maximum penetration force 
required for a $4 \mathrm{~mm}$ diameter stainless probe to penetrate into an apple wedge to a depth of $5 \mathrm{~mm}$ at a rate of $5 \mathrm{~mm} \mathrm{~s}^{-1}$. Apple wedges were placed perpendicular to the probe to allow penetration in the centre. Five pieces from each tray were used per treatment.

\subsection{Colour measurement}

Colour values of the cut apple surfaces were measured with a colorimeter HunterLab MiniScan XE Plus (Hunter Associates Laboratory, Inc, Reston, VA, USA). Colour was measured using the CIELAB, L* (lightness) $\mathrm{C}^{*}$ (chroma) h (hue angle). Illuminant D65 and $10^{\circ}$ observer angle were used. The instrument was calibrated using a standard white reflector plate. Samples were taken from three trays per treatment, and five readings (five slices) were made in each tray. The browning index (BI) was calculated as follows: $\mathrm{BI}=[100(\mathrm{x}-0.31)] / 0.172$ where: $\mathrm{x}=(\mathrm{a}+1.75 \mathrm{~L}) /(5.645 \mathrm{~L}+\mathrm{a}-3.012 \mathrm{~b})$.

The browning index (BI) is defined as brown colour purity and usually used as indicator of the browning extent in sugar containing food products (Buera et al., 1986; Guerrero et al., 1996).

\subsection{Microbiological analysis}

The microflora was measured every two days for ten days of storage at $5^{\circ} \mathrm{C}$. One slice of apple from each treatment was dipped in equivalent volume of sterile peptone water $1 \%$ (e.g., a slice of $10 \mathrm{~g}$ was dipped in $1 \mathrm{~mL}$ of peptone water) for $1 \mathrm{~min}$. A $1 \mathrm{~mL}$ aliquot of the solution was then serially diluted in sterile peptone water $1 \%$ in $(1: 10)$ to a final dilution of $10^{3}$. Separate $1 \mathrm{~mL}$ aliquots of each of the dilutions from $10^{0}$ to $10^{3}$ were withdrawn and poured on $3 \mathrm{M}^{\mathrm{TM}}$ Petrifilm ${ }^{\mathrm{TM}}$ to detect mould and yeast (three plates per dilution), and $3 \mathrm{M}^{\mathrm{TM}}$ Petrifilm ${ }^{\mathrm{TM}}$ to detect E. coli/coliform (three plates per dilution), and $3 \mathrm{M}^{\mathrm{TM}} \mathrm{Tecra}^{\mathrm{TM}}$ Salmonella Visual Immunoassay for Salmonella spp. (three kit wells per sample). The plates for yeast and mould were incubated at $25^{\circ} \mathrm{C}$ for $72 \mathrm{~h}$; plates for E. coli and coliform were incubated at $45^{\circ} \mathrm{C}$ and $35^{\circ} \mathrm{C}$ for $24 \mathrm{~h}$, respectively. The microorganisms were counted with an automated colony counter Phoenix CP 600 Plus (Araraquara, SP, Brazil). The results were expressed as CFU g $\mathrm{g}^{-1}$ of apples. For Salmonella, the samples were primary enriched in Buffered Peptone Water for $24 \mathrm{~h}$ at $35^{\circ} \mathrm{C}$ followed by the secondary enrichment in Rappaport Vassiliads Broth for $20 \mathrm{~h}$ at $42^{\circ} \mathrm{C}$. For post-enrichment, samples were enriched in M-Broth for $8 \mathrm{~h}$ at $36^{\circ} \mathrm{C}$. The results were interpreted comparing wells of the samples to the well of positive control.

\subsection{Statistical analysis}

A completely randomised design was used with three treatments, six days (ten days of storage with analyses every two days: $0,2,4,6,8$ and 10) and five replications, a total of 90 samples. Each tray constituted on experimental unit. The effects of treatments, storage days and interaction for each original isolated variable were tested by general linear model (GLM), using a complete factor analysis in the analysis of variance (ANOVA). Significant differences among the levels of main effects (treatment and storage day) were compared by Tukey's tests at the $5 \%$ level of significance. The multivariate structure contained in the original data was explored by multivariate analysis of factors. Analyses were run using the software Statistica 7.0 (STATSOFT, Inc., 2004). 


\section{Results and discussion}

In Table 1 is summarised the main results from samples colorimetric, texture and headspace gases analysis. In these data, two factors account for $63.4 \%$ of the variability. Residues were normally distributed with zero mean and constant variance for both factors F1 (lightness, chroma and hue angle) and $\mathrm{F} 2\left(\mathrm{CO}_{2}\right.$ and ethylene).

Table 1 Factor analysis loadings of colour (lightness, chroma and hue angle), headspace gas composition $\left(\mathrm{CO}_{2}\right.$ and ethylene) and texture of fresh-cut gala apples stored for ten days at $5^{\circ} \mathrm{C}$

\begin{tabular}{lcc}
\hline & Factor 1 & Factor 2 \\
& Lightness, chroma and hue angle & $\mathrm{CO}_{2}$ and ethylene \\
\hline Lightness & 0.864468 & 0.095477 \\
Chroma & -0.889532 & 0.076536 \\
Hue angle & 0.933229 & -0.101667 \\
$\mathrm{CO}_{2}$ & 0.102662 & -0.796527 \\
Ethylene & 0.004539 & 0.839777 \\
Texture & 0.079827 & 0.121183 \\
\hline *Expl. var. & 2.426421 & 1.379676 \\
$* *$ Prp. totl. & $40.44 \%$ & $22.99 \%$ \\
\hline
\end{tabular}

Notes: *Explained variance; **proportion of variation explained.

\subsection{Colour changes}

The first factor (colour) accounts for $40.44 \%$ of data variability. Positive scores indicate lighter slices. Scores closer to zero or negative indicates that apple slices developed a browning colouration (Figure 1). These results agree with the results from browning index for each treatment shown in Figure 2.

Figure 1 Colouration scores in dipped (1\% AA $+2 \% \mathrm{CA})$, coated $(1 \% \mathrm{AA}+2 \% \mathrm{CA}+$ chitosan $)$ and uncoated (control) apple slices during storage at $5^{\circ} \mathrm{C}$

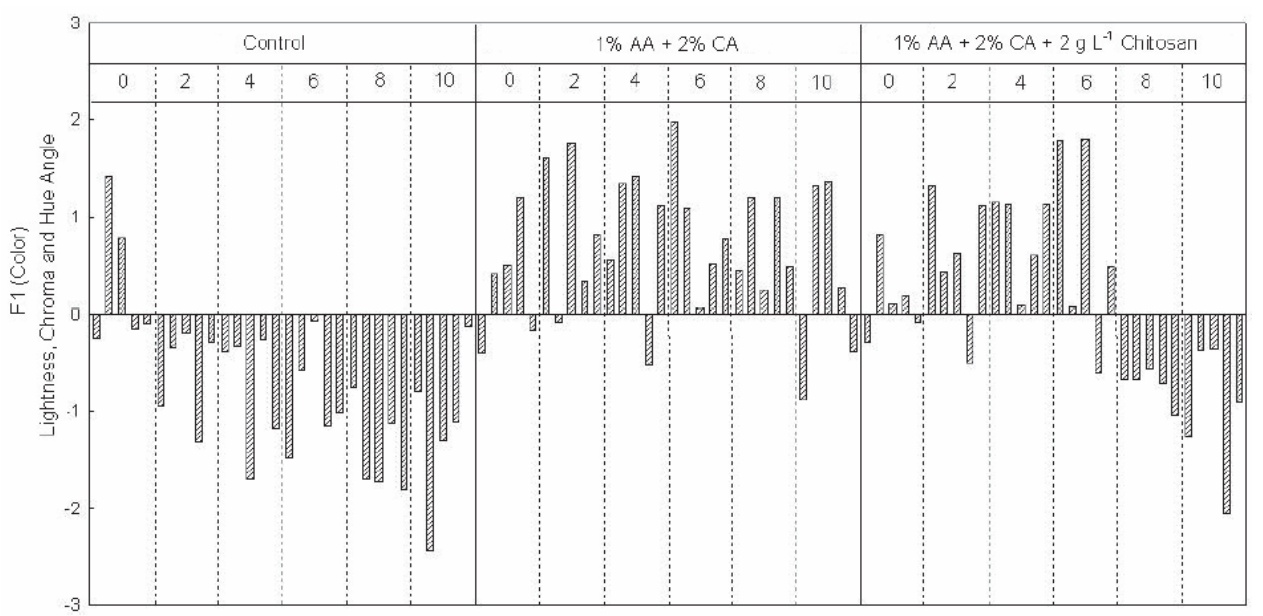


Figure 2 Browning index (BI) from apple slices dipped in 1\% AA + 2\% CA; $1 \% \mathrm{AA}+2 \% \mathrm{CA}+$ $2 \mathrm{~g} \mathrm{~L}^{-1}$ chitosan and control stored for ten days at $5^{\circ} \mathrm{C}$

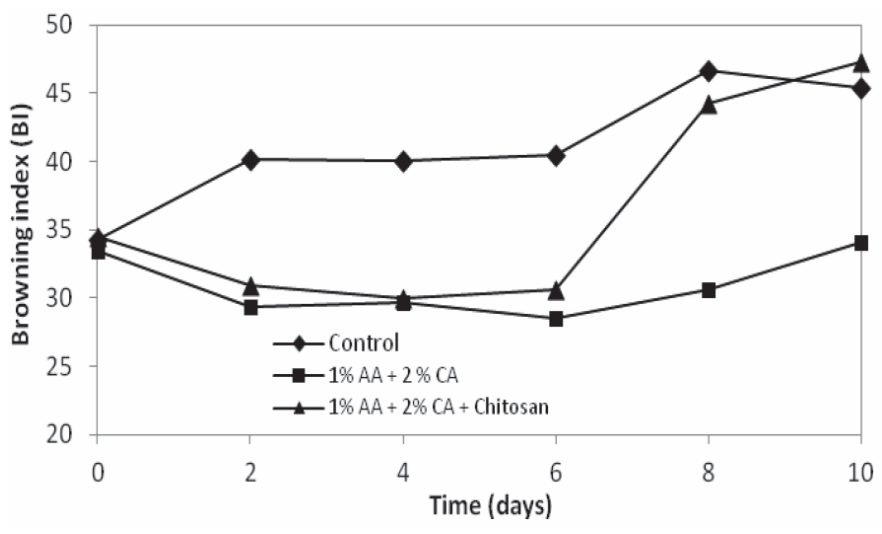

Lightness varies from black to white on a scale of 0 to 10 and represent lighter or darker colours, hue angle is the attribute of colour perception by means of which and an object is judged to be red, yellow, green, blue, etc., and chroma represents degree of departure from grey toward pure chromatic colour (McGuire, 1992). The increase in chroma means an increase in pigments and it is directly related to the browning of apple slices.

In this study, there is a positive correlation with lightness and hue angle and negative correlation for chroma (Table 1); evidencing that if the values of chroma increase during storage, the lightness and hue angle values tend to decrease. In fact, Rocha and Morais (2003) observed the same pattern of changes in colouration during storage of fresh-cut apples for ten days at $4^{\circ} \mathrm{C}$.

The samples initially showed weak yellowish hue $\left(\sim 87^{\circ}\right)$ and tended to weak orange hue $\left(\sim 82^{\circ}\right)$ during storage. The control showed the lowest values of lightness and hue angle, and highest values for chroma factors. Apple slices from the control treatment were the darkest suggesting that this treatment was the least efficient for maintaining the quality of apple slices (Figure 1).

Factor 1 scores have similar characteristics at the beginning of the evaluation for all treatments. However, during storage was noticed that the control gradually became darker. Darkening of the colour increased by $32 \%$ at the of the storage period as compared to initial values (Figure 2).

The apple slices dipped in $1 \% \mathrm{AA}+2 \% \mathrm{CA}$ maintained their colouration score during storage with lighter slices (Figures 1 and 2). Browning in apples is caused by the enzymes polyphenol oxidase and peroxidase. When slices are in contact with oxygen, production of dark pigments occurs affecting flavour and aroma (Rojas-Grau et al., 2008 ). Treatment with $1 \% \mathrm{AA}+2 \% \mathrm{CA}$ was the most effective in preserving the colour (Figure 1).

The samples coated with $1 \% \mathrm{AA}+2 \% \mathrm{CA}+$ chitosan maintained good colouration until the sixth day of storage, similar to the $1 \% \mathrm{AA}+2 \% \mathrm{CA}$ treatment. Afterward, they became darker and similar to the control. Chien et al. (2007) likewise reported that colour was preserved for seven days at $6^{\circ} \mathrm{C}$ when fresh-cut mango was coated with different concentration of chitosan dissolved in acetic acid. Similarly, Olivas et al. (2007) did not find significant differences among alginate-based coating, alginate-acetylated 
monoglyceridelinoleic acid-based coating, alginatebutter-linoleic acid-based coating, and the control in apple slices during the first six days of storage; however, after day 8 the control was $20 \%$ darker.

Nevertheless, the colour preservation measured in samples coated with chitosan associated to AA and AC in the first week of storage is quite superior to similar analyses performed on sliced apples coated only with chitosan with no antibrowning, as reported by Assis et al. (2012).

\subsection{Changes in headspace gas composition}

The second factor $\left(\mathrm{CO}_{2}\right.$ and ethylene) accounts for $22.9 \%$ of data variability. It shows a positive correlation for ethylene and negative for $\mathrm{CO}_{2}$. It evidences that there was an increasing tendency in the ethylene values while $\mathrm{CO}_{2}$ values showed a slight decrease (Figure 3).

Figure $3 \quad \mathrm{CO}_{2}$ and ethylene scores in dipped (1\% AA + 2\% CA), coated $(1 \% \mathrm{AA}+2 \% \mathrm{CA}+$ chitosan) and uncoated (control) apple slices during storage at $5^{\circ} \mathrm{C}$

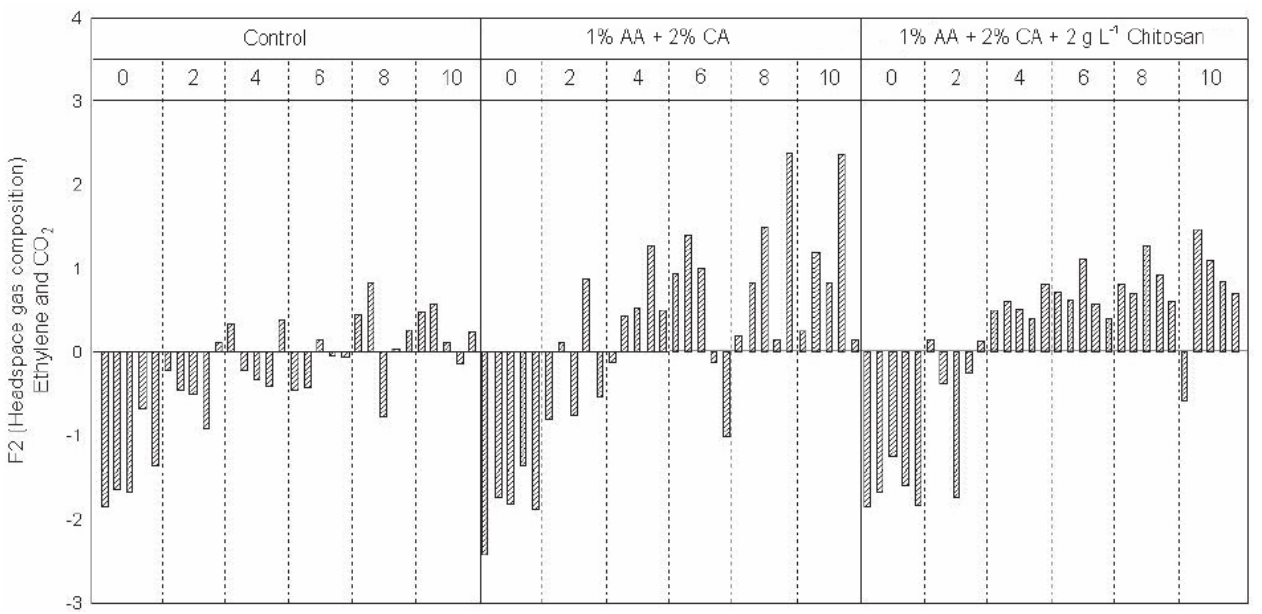

Positive scores indicate that samples had higher concentration of ethylene and negative scores indicate low concentration of this gas. Since $\mathrm{CO}_{2}$ values remained practically constant, ethylene may be assumed as responsible for the changes observed in the scores for all treatments during storage period (Figure 3).

Despite the small variation in the $\mathrm{CO}_{2}$ values throughout the storage, an increase in the concentration was detected on the first day of analysis for all treatments (Figure 4), which may be related to the physical stress caused by minimal processing (Rosen and Kader, 1989).

In this study, the three treatments showed the same pattern during the storage time concerning the synthesis of ethylene, characterised by a daily increase of gas content (Figure 4). According to Abeles et al. (1992), the occurrence of injuries in plant tissues increases ethylene production reaching its maximum level within 6 to 12 hours. 
Figure $4 \mathrm{CO}_{2}$ and ethylene headspace gas concentration in trays containing dipped (1\% $\mathrm{AA}+2 \%$ $\mathrm{CA})$, coated (1\% AA + 2\% CA + chitosan) and uncoated (control) apple slices during storage at $5^{\circ} \mathrm{C}$
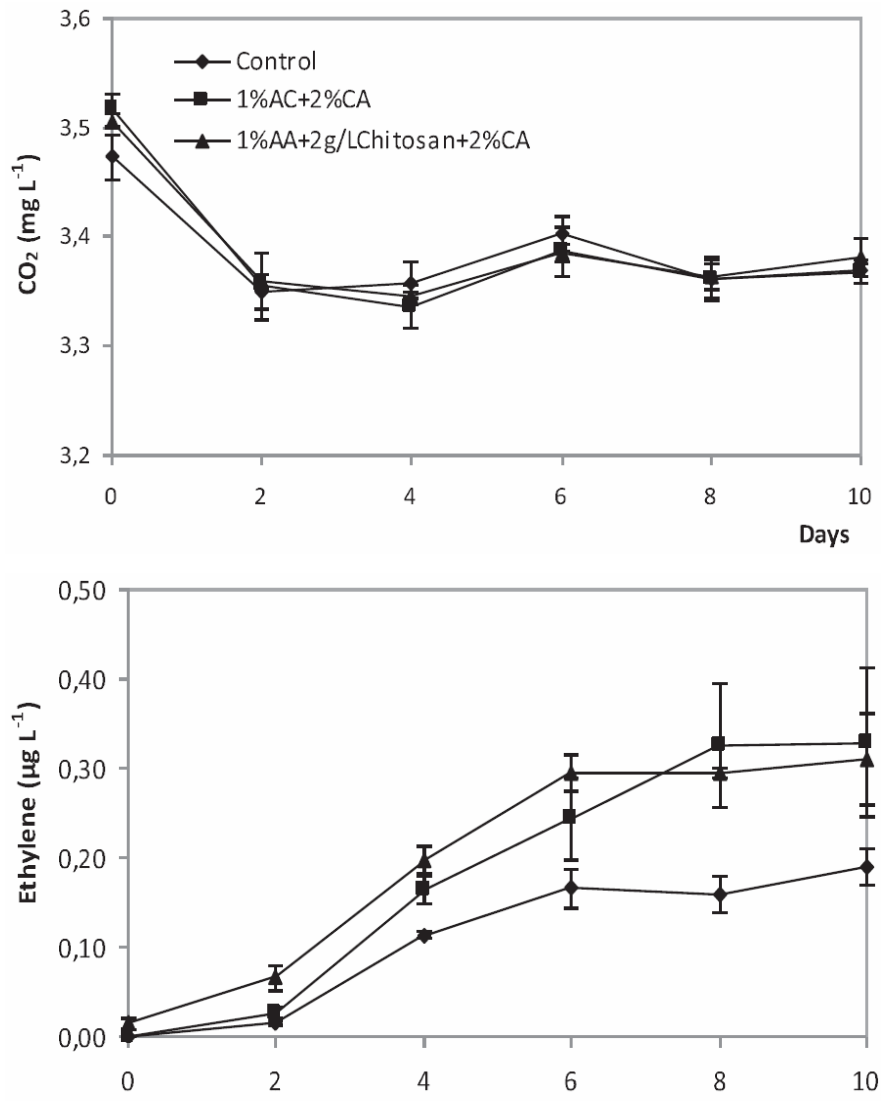

Note: Data shown are the means ( \pm standard deviation).

The control samples showed the lowest mean Factor 2, the lower concentration of gases was detected throughout the storage period. For samples dipped in $1 \% \mathrm{AA}+2 \% \mathrm{CA}$ and in $1 \% \mathrm{AA}+2 \% \mathrm{CA}+$ chitosan, the scores became positive showing a tendency of increase in ethylene concentration from the fourth day. However, the detected concentration of both $\mathrm{CO}_{2}$ and ethylene were low for all treatments (Figure 4). This agrees with results reported by Rojas-Grau et al. (2007) in which a low level in ethylene production was measured in samples coated with alginate-apple puree-based films. Vargas et al. (2006) found similar behaviour in the respiratory rate of strawberry coated with chitosan combined with oleic acid in first three days of storage at $4{ }^{\circ} \mathrm{C}$.

It is well known that ethylene production is stimulated when plant tissues are injured and it can accumulate in packages of fresh-cut product leading to undesirable effects (Watada and Qi, 1999). Thereby, a well elaborated edible coating can assure the formation of a modified atmosphere inside the fruit reducing levels of internal oxygen minimising the ethylene production (Olivas and Barbosa-Canovas, 2009). Storage temperature has a major effect on metabolic activity (Garcia and Barrett, 2002), and should be associated to additional preservative procedures. 


\subsection{Texture changes}

Edible coatings can preserve texture of fruit and vegetables by reducing water loss and preventing dehydration (Lin and Zhao, 2007) and serving as carriers of texture enhancers, such as calcium chloride (Olivas and Barbosa-Canovas, 2009).

Concerning texture analyses, the load values of the variable were very low in both F1 and F2 factors and not considered as relevant in this study. An individual analysis of variance showed no significant differences between means of texture for treatments and storage days $(p>0.05)$ and showed homogeneity in variances. Neither of the treatments affected texture, with all means ranging from 9.0 to $10.0 \mathrm{~N}$.

Supapvanich et al. (2011) likewise found that fresh-cut apple texture remained constant when stored at different cold temperature. However, chitosan coating has been reported as efficient in avoiding tissue softening in cut (Qi et al., 2011) and intact apples (Jorge et al., 2011), what can be a factor of polymer concentration in the formed coated. Similarly, Gonzalez-Aguilar et al. (2009) reported that texture of fresh-cut papaya was also maintained for a period when slices were coated with chitosan. Ducamp-Collin et al. (2009) also found that fresh-cut mango texture was preserved for nine days at $4{ }^{\circ} \mathrm{C}$ when treated chitosan solution $(0.75 \%$ chitosan $+3 \%$ citric acid $)$.

The low concentration of ethylene as found in all treatments in this study may also interfere in delaying the tissue softening. Several studies have showed the effect of ethylene in accelerating softening, as Agar et al. (1999), who reported that the removal of ethylene from the storage atmosphere increased retention of firmness in fresh-cut kiwi.

\subsection{Microbiological analysis}

Figure 5 shows the effect of chemical dip and chitosan coating on the growth of moulds and yeasts on fresh-cut apple stored for ten days at $5^{\circ} \mathrm{C}$. The initial count of moulds and yeast of fresh-cut apple was low for all samples. Samples coated with $1 \%$ AA $+2 \%$ CA + chitosan and control showed initial count of $1.4 \mathrm{CFU} \mathrm{mL}^{-1}$ and samples dipped in $1 \% \mathrm{AA}$

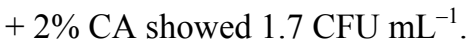

Figure 5 Effects of treatments on moulds and yeasts growth $\left(\log \mathrm{CFU} \mathrm{mL} \mathrm{L}^{-1}\right)$ of apple slices

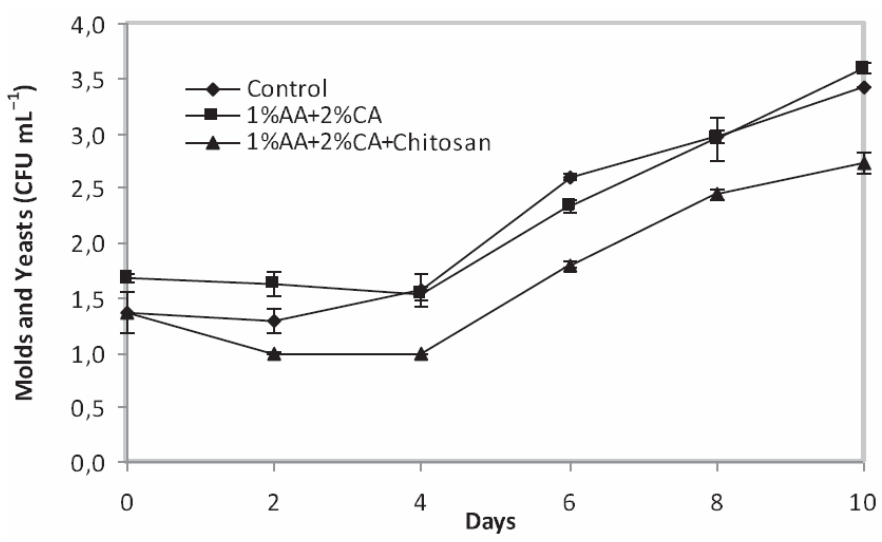

Note: Data shown are the means ( \pm standard deviation). 
The chitosan coating treatment was the most effective in inhibiting growth of these microorganisms from the second day of storage until the end of experiment. In fact, the antimicrobial activity of chitosan against a wide range of foodborne filamentous fungi, yeast, and bacteria has made it a potential natural food preservative (Goy et al., 2009; No et al., 2007; Sudharshan et al., 1992). Rojas-Grau et al. (2007) also found low counts of moulds and yeasts, below $2 \log \mathrm{CFU} \mathrm{mL} \mathrm{m}^{-1}$, in apple slices coated with alginate-apple puree coatings containing essential oils. Gonzalez-Aguilar et al. (2009) reported the effect of chitosan in preventing deterioration and found that this coating inhibited the growth of moulds and yeasts on fresh-cut papaya stored at $5^{\circ} \mathrm{C}$.

The growth of Salmonella, and total and fecal coliforms was also evaluated in this research; however, none of these microorganisms was detected.

\section{Conclusions}

In conclusion, we can state that samples coated with $1 \% \mathrm{AA}+2 \% \mathrm{CA}+$ chitosan and $1 \%$ $\mathrm{AA}+2 \% \mathrm{CA}$ treatment do maintain good colouration until the sixth day of storage. Additionally all treatments preserve the texture and low concentration of C 02 and ethylene during storage at low temperature. The formulation with chitosan has the additional effect in being effective in inhibiting the growth of moulds and yeast on cut apple surfaces increasing the life-time for consumption. Coatings based on chitosan could be a good choice for fresh-cut coatings by associating antibrowning agent assuring superior activity than simple acid-based dipping.

\section{Acknowledgements}

This work was supported by Coordenagao de Aperfeigoamento de Pessoal de Nivel Superior (CAPES) and Brazilian Agricultural Research Corporation (EMBRAPA). The abstract of this article was presented on the 6th National Meeting of Fruits and Vegetables Minimally Processed, 26-28 October 2011, Brazil.

\section{References}

Abeles, F.B., Morgan, P.W. and Saltveit Junior, M.E. (1992) Ethylene in Plant Biology, 2nd ed., $414 p$, Academic Press, San Diego.

Agar, I.T., Massantini, R., Hess-Pierce, B. and Kader, A.A. (1999) 'Postharvest $\mathrm{CO}_{2}$ and ethylene production and quality maintenance of fresh-cut kiwifruit slices', Journal of Food Science, Vol. 64, No. 3, pp.433-440.

Assis, O.B.G., Scramin, J.A., Correa, T.A., Britto, D. and Forato, L.A. (2012) 'A comparative evaluation of integrity and colour preservation of sliced apples protected by chitosan and zein edible coatings', Revista Iberoamericana de Tecnologia Postcosecha, Vol. 13, No. 1, pp.76-85.

Buera, M.P., Lozano, R.D. and Petriella, C. (1986) 'Definition of colour in the non enzymatic browning process', Die Farbe, Vols. 32/33, pp.318-322.

Cantwell, M. and Suslow, T.V. (2002) 'Postharvest handling systems: fresh-cut fruits and vegetables', in Kader, A.A. (Ed.): Postharvest Technology of Horticultural Crops, pp.445-463, Univ. California, Division of Horticultural and Natural Resources, Davis. 
Chien, P-J., Sheu, F. and Yang, F-H. (2007) 'Effects of edible chitosan coating on quality and shelf life of sliced mango fruit', Journal of Food Engineering, Vol. 78, No. 1, pp.225-229.

Ducamp-Collin, M.N., Reyes, M., Lebrun, M. and Freire, M. (2009) 'Fresh-cut mango fruits: evaluation of edible coatings', Acta Horticulturae, Vol. 820, No. 1, pp.761-767.

Garcia, E. and Barrett, D.M. (2002) 'Preservative treatments for fresh-cut fruits and vegetables', in Lamikanra, O. (Ed.): Fresh-cut Fruits and Vegetables: Science, Technology and Market, pp.267-303, CRC Press, Boca Raton, FL.

Gonzalez-Aguilar, G.A., Valenzuela-Soto, E., Lizardi-Mendoza, J., Goycoolea, F., Martinez-Tellez, M.A., Villegas-Ochoa, M.A., Monroy-Garcia, I.N. and Ayala-Zavala, F.F. (2009) 'Effect of chitosan coating in preventing deterioration and preserving the quality of fresh-cut papaya 'Maradol', Journal of the Science of Food and Agriculture, Vol. 89, No. 1, pp.15-23.

Goy, R.C.,; Britto, D. and Assis, O.B.G. (2009) 'A review of the antimicrobial activity of chitosan', Polfmeros: Ciencia e Tecnologia, Vol. 19, No. 3, pp.241-247.

Guerrero, S., Alzamora, S.M. and Gerschenson, L.N. (1996) 'Optimization of a combined factors technology for preserving banana puree to minimize colour changes using response surface methodology', J. Food Eng., Vol. 28, No. 3, pp.307-322.

Jorge, P.C.S., Nucci, M., Rizzo, J.S., Assis, O.B.G. and Monteiro, M. (2011) 'Maga Royal Gala revestida com quitosana estocada a temperatura ambiente', Boletim do Centro de Pesquisa e Processamento de Alimentos, Vol. 29, No. 2, pp.253-2011 (in Portuguese).

Lamikanra, O. (Ed.) (2002) Fresh-cut Fruits and Vegetables: Science, Technology and Market, 467p, CRC Press, Boca Raton, FL, RC Press, Boca Raton, FL.

Lin, D. and Zhao, Y. (2007) 'Innovations in the development and application of edible coatings for fresh and minimally processed fruits and vegetables', Comprehensive Reviews in Food Science and Food Safety, Vol. 6, No. 3, pp.60-75.

McGuire, R.G. (1992) 'Reporting of objective color measurements', HortScience, Vol. 27, No. 12, pp.1254-1255.

No, H.K., Meyers, S.P., Prinyawiwatkul, W. and Xu, Z. (2007) 'Applications of chitosan for improvement of quality and shelf life of foods: a review', Journal of Food Science, Vol. 72, No. 5, pp.87-100.

Olivas, G.I. and Barbosa-Canovas, G.V. (2009) 'Edible films and coatings for fruits and vegetables', in Embuscado, M.E. and Huber, K.C. (Ed.): Edible Films and Coatings for Food Applications, pp.211-244, Springer, New York, NY.

Olivas, G.I., Mattinson, D.S. and Barbosa-Canovas, G.V. (2007) 'Alginate coatings for preservation of minimally processed 'Gala' apples', Postharvest Biology and Technology, Vol. 45, No. 1, pp.89-96.

Qi, H., Hu, W., Jiang, A., Tian, M. and Li, Y. (2011) 'Extending shelf-life of fresh-cut 'Fuji' apples with chitosan-coatings', Innovative Food Science and Emerging Technologies, Vol. 12, No. 1, pp.62-66.

Rocha, A.M.C.N. and Morais, A.M.M.B. (2003) 'Shelf life of minimally processed apple (cv. Jonagored) determined by colour changes', Food Control, Vol. 14, No. 1, pp.13-20.

Rojas-Grau, M.A., Raybaudi-Massilia, R.M., Soliva-Fortuny, R.C., Avena-Bustillos, R.J., Mchugh, T.H. and Martin-Belloso, O. (2007) 'Apple puree-alginate edible coating as carrier of antimicrobial agents to prolong shelf-life of fresh-cut apples', Postharvest Biology and Technology, Vol. 45, No. 2, pp.254-264.

Rojas-Grau, M.A., Soliva-Fortuny, R. and Martin-Belloso, O. (2008) 'Effect of natural antibrowning agents on color and related enzymes in fresh-cut 'Fuji' apples as an alternative to the use of ascorbic acid', Journal of Food Science, Vol. 73, No. 6, pp.267-272.

Rosen, J.C. and Kader, A.A. (1989) 'Postharvest physiology and quality maintenance of sliced pear and strawberry fruits', Journal of Food Science, Vol. 54, No. 3, pp.656-659. 
Sonti, S., Prinyawiwatkul, W., No, H.K. and Janes, M.E. (2003) 'Maintaining quality of fresh-cut apples with edible coating during 13-days refrigerated storage', IFT Annual Meeting Book of Abstracts, p.45, Institute of Food Technologists, New Orleans, LA.

STATSOFT, Inc. (2004) STATISTICA (Data Analysis Software System), Version 7 [online] http://www.statsoft.com.

Sudarshan, N.R., Hoover, D.G and Knorr, D. (1992) 'Antibacterial action of chitosan', Food Biotechnology, Vol. 6, No. 3, pp.257-272.

Supapvanich, S., Pimsaga, J. and Srisujan, P. (2011) 'Physicochemical changes in fresh-cut wax apple (Syzygium samarangenese [Blume] Merrill \& L.M. Perry) during storage', Food Chemistry, Vol. 127, No. 3, pp.912-917.

Toivonen, P.M.A., Wiersma, P.A., Hampson, C. and Lannard, B. (2010) 'Effect of short-term air storage after removal from controlled-atmosphere storage on apple and fresh-cut apple quality', Journal of the Science of Food and Agriculture, Vol. 90, No. 4, pp.580-585.

Vargas, M., Albors, A., Chiralt, A. and Gonzalez-Martinez, C. (2006) 'Quality of cold-stored strawberries as affected by chitosan-oleic acid edible coatings', Postharvest Biology and Technology, Vol. 41, No. 2, pp.164-171.

Wang, H., Feng, H. and Luo, Y. (2007) 'Control of browning and microbial growth on fresh-cut apples by sequential treatment of sanitizers and calcium ascorbate', Journal of Food Science, Vol. 72, No. 1, pp.1-7.

Watada, A.E. and Qi, L. (1999) 'Quality of fresh-cut produce', Postharvest Biology and Technology, Vol. 15, No. 3, pp.201-205. 